\title{
O que é prosódia? Definições, funções e aplicações
}

\author{
Thales Nascimento BUZAN® \\ Universidade Federal de Juiz de Fora (UFJF)
}

\section{RESUMO}

O objetivo desta resenha é apresentar a mesa redonda Prosódia: voz, estrutura e expressão, transmitida no dia 31/05/2020 e organizada pelo evento Abralin Ao Vivo. Destacam-se também pontos interessantes discutidos no chat simultâneo à apresentação. A pesquisadora Luciana Lucente e o pesquisador Pablo Arantes introduzem a mesa abordando a definição de prosódia, elucidando suas funções de proeminência, segmentação e função discursiva. Em seguida os pesquisadores convidados da mesa, Albert Rilliard e Alexsandro Meireles, abordam questões mais específicas que dizem respeito à prosódia, como sua multimodalidade e os quatro códigos biológicos e a qualidade de voz na fala e no canto.

○ OPEN ACCESS EDITADO POR Raquel Freitag

AVALIADO POR Luciana Lucente

DATAS Recebido: 07/06/2020 Aceito: 04/07/2020 Publicado: 20/07/2020

COMO CITAR

Buzan, T. N. (2020). O que é prosódia? Definições, funções e aplicações. Revista da Abralin, v. 19, n. 2, p. 1-4, 2020.

\section{ABSTRACT}

The aim of this review is to present the round table Prosódia: voz, estrutura e expressão, broadcasted on May 31st/2020 and organized by the event Abralin Ao Vivo. It also highlights interesting points discussed in the chat simultaneously with the presentation. Professors Luciana Lucente and Pablo Arantes introduced the table by approaching the definition of prosody, elucidating its functions of prominence, segmentation and discursive function. Next, the invited researchers, Albert Rilliard and Alexsandro Meireles, advance to more specific issues related to prosody, such as its multimodality and the four biological codes, and the quality of voice in speech and singing. 


\section{REVISTA DA ABRALIN}

PALAVRAS-CHAVE

Prosódia. Multimodalidade. Canto.

\section{KEYWORDS}

Prosody. Multimodality. Singing.

A mesa redonda foi apresentada em duas partes. A primeira parte foi apresentada pelos pesquisadores e professores Luciana Lucente e Pablo Arantes, que também moderaram a mesa.

O professor Pablo Arantes começa sua fala trazendo definições de prosódia, contrastando, de forma muito clara e didática, definições negativas com as positivas. Dessa forma, ele apresenta as primeiras definições nas quais a prosódia seria o que ela não é, a exemplo de ser tudo aquilo que não é do nível segmental, ou ser o que as convenções da escrita não representam. É salientado, entretanto, que essas definições não são tão precisas, já que a questão da duração faz parte dos segmentos, mas também é manipulada pela prosódia, portanto não seria clara a desvinculação entre o que é segmental e o que é suprassegmental. Com relação à escrita, alguns sinais diacríticos, como o ponto de interrogação e exclamação e a vírgula, representam parcialmente algumas informações prosódicas, essa distinção sofre do mesmo problema.

Além das definições negativas, há ainda as definições positivas, que definem prosódia como melodia, ritmo e qualidade de voz, mas que não deixam de ter problemas por definirem prosódia a partir de fenômenos que, de certa forma, assim como as definições negativas, também dialogam com os segmentos.

Uma definição mais interessante e pertinente é chamar atenção para as funções exercidas pela prosódia, que o professor enumera como (a) proeminência, (b) segmentação ou demarcação e (c) função discursiva. O professor explica que as funções, por sua vez, são executadas de quatro principais formas: (i) duração, englobando ritmo e tempo; (ii) F0, ou frequência fundamental, ligada aos aspectos melódicos da produção fala, como pitch, que nos dá informação de grave e agudo; (iii) intensidade, cujo termo em inglês é loudness, que nos dá a informação de alto e baixo; por último, o professor apresenta o (iv) timbre, o qual ele explica que é um campo mais qualitativo e que trabalha com a qualidade da voz, muito relacionado à música.

A professora Luciana Lucente passa a ter o turno de fala para dar sequência à introdução e, de maneira sucinta e didática, a pesquisadora apresenta quais são os constituintes prosódicos e sua hierarquia como uma introdução à função (b). Para isso, a professora organiza sua fala começando a falar da sílaba, fonológica e fonética, com a imagem clássica de sua hierarquia com ataque e rima com seu núcleo e coda - e com exemplos do português brasileiro. As imagens das árvores dos constituintes despertam a manifestação do chat e algumas pessoas relatam fazer muito tempo que estudaram esse assunto, mostrando que a professora acertou ao abordar o assunto dessa forma. 


\section{REVISTA DA ABRALIN}

Tendo feito essa introdução, a professora passa para a função de segmentação (b) propriamente dita, que consiste em reconhecer as unidades constitutivas da fala, isto é, há a delimitação dos constituintes prosódicos, diz respeito à percepção de fronteiras terminais e não-terminais na cadeia da fala e negocia com princípios gerais, como eurritmia. Antes de trazer dados de fala, no software de análise de áudio praat, para exemplificar sua apresentação, a professora finaliza sua explicação teórica sintetizando os fenômenos da segmentação, sendo eles as pausas, os acentos frasais e os acentos tonais. Os exemplos no praat são elucidativos e apresentam aos ouvintes a noção do caráter prático que a pesquisa em prosódia carrega e seu real objeto de estudo: a fala.

O professor Pablo retoma o turno para falar sobre a função (a), que diz respeito à saliência relativa de um elemento prosódico em relação a outro, isto é, a capacidade de chamar mais atenção para um item em relação aos demais. Ele explica, com ótimos exemplos sonoros no praat, que isso pode acontecer em diferentes níveis da hierarquia, na sílaba, no pé métrico, na palavra ou no sintagma, tendo como fenômenos da saliência os acentos lexical, secundário e frasal, bem como o fenômeno de foco.

O bloco introdutório é finalizado pela professora Luciana, que apresenta a última função, (c), dividida em dois planos: linguístico e expressivo. Enquanto o primeiro marca turno de fala e modalidade da fala, o segundo sinaliza atitude, afeto e indexicalidade e qualidade da voz.

Com a primeira parte concluída, o professor convidado Albert Rilliard inicia a segunda parte da mesa redonda argumentando que a produção de fala é multimodal e defende bem seu ponto de vista falando sobre as performances face-a-face, que utilizam o corpo todo para dar significado com respiração, gestos, expressões faciais, entre outras. Enquanto o professor apresenta o efeito McGurk, os efeitos fisiológicos do falante e a face como contexto para a interpretação da prosódia para defender que a percepção da fala também é multimodal, no chat surge uma questão muito interessante e os ouvintes dialogam sobre os famosos manuais didáticos que não abordam questões prosódicas e há sugestões de projetos sendo desenvolvidos.

Sua apresentação segue tocando em pontos muito importantes, como a performance do falante para gerar significado e como a questão do simbolismo sonoro pode afetar a tradição da arbitrariedade do léxico. Em seguida, ele apresenta quatro códigos biológicos que nos auxiliam no significado, são eles: o código de frequência, do esforço, da respiração e, por último, o sirenic code. Outro fator valoroso é a experiência emocional, exemplificado e explicado pelo professor, e como ela envolve nossa expressão corporal.

O professor termina sua fala, recebendo elogios de mestrandos no chat e alertando que, mesmo que os códigos expliquem a maioria das variações prosódicas em diversas línguas, sendo potencialmente universais, ainda há variações culturais, como no exemplo elucidativo da fala de um japonês somente com o áudio e depois com áudio e vídeo e a diferença de percepção de ambos para um ouvido francês, já que ele é um falante nativo de francês.

O último bloco da mesa é apresentado pelo convidado Alexsandro Meireles, o qual aborda a qualidade da voz. Para mostrar como os sons são produzidos fisiologicamente, ele faz uma apresentação extensa do trato vocal, da laringe e de seus músculos com os respectivos movimentos. Ele exemplifica com bandas e cantores, fazendo até mesmo uma exímia pequena performance de 


\section{REVISTA DA ABRALIN}

algumas notas musicais e a relação delas com movimentos musculares na laringe. É explicado que, por mais que haja diferenças anatômicas entre homens e mulheres, é possível que mulheres cantem notas muito baixas e homens cantem notas muito altas.

Em um segundo momento ele traz a definição de qualidade da voz na fala e no canto usando o Voice Profile Analysis Scheme, juntamente com os modos de fonação básicos e compostos, e fecha defendendo que o canto pode ser estudado dentro da prosódia por estar presente justamente na 10th International Conference on Speech Prosody 2020, na qual ele publicou um artigo sobre qualidade de voz.

A mesa redonda é finalizada pelos moderadores com a resposta de algumas perguntas e o chat vibra com aplausos e elogios a essa mesa de notável importância que, não só sintetizou o que é prosódia com ótimos exemplos, como também a colocou em diálogo com a multimodalidade e o canto.

\section{REFERÊNCIAS}

PROSÓDIA voz, estrutura e expressão. Conferência apresentada por Luciana Lucente, Pablo Arantes, Albert Rilliard e Alexsandro Meireles [S.I., s.n], 2020. 1 vídeo (2h 24min 05s). Publicado pelo canal da Associação Brasileira de Linguística. Disponível em: https://www.youtube.com/watch?v=zR6QWKBM3Oc . Acesso em: 14 jul 2020. 